\title{
Ant assemblage (Hymenoptera: Formicidae) in three wind farms in the State of Paraná, Brazil
}

\author{
J. A. Lutinski ${ }^{*}$, L. Baucke ${ }^{b}$, M. Filtro ${ }^{b}$, M. A. Busato ${ }^{a}$, A. C. Knakiewicz ${ }^{c}$ and F. R. M. Garcia \\ aPost Graduate Program in Health Sciences, Universidade Comunitária da Região de Chapecó - UNOCHAPECÓ, \\ Avenida Senador Attílio Fontana, 591-E, Efapi, CP 1141, CEP 89809-000, Chapecó, SC, Brazil \\ 'bimpacto Assessoria Ambiental, San Francisco, 65, Maria Goretti, CEP 89801-451, Chapecó, SC, Brazil \\ ${ }^{\mathrm{c}}$ Area of Exact and Environmental Sciences, Universidade Comunitária da Região de Chapecó - UNOCHAPECÓ, \\ Avenida Senador Attílio Fontana, 591-E, Efapi, CP 1141, CEP 89809-000, Chapecó, SC, Brazil \\ dPost Graduate Program of Entomology, Institute of Biology, Universidade Federal de Pelotas - UFPel, CP 354 , \\ CEP 96010-900, Pelotas, RS, Brazil \\ *e-mail: junir@unochapeco.edu.br
}

Received: September 12, 2015 - Accepted: December 09, 2015 - Distributed: February 28, 2017

(With 3 figures)

\begin{abstract}
The transformation of natural habitats into areas destined to agriculture or projects of energy production has generated a growing concern about the impact on biological diversity. Thus, this study evaluated the diversity of ants in agroecosystems in the area of direct influence of three wind farms in the municipality of Marmeleiro, State of Paraná and examined the association of occurrences with sampling periods. To this end, four samplings were conducted in 2013, one per season. Pitfalls, Malaise trap and Net sweep were used. The assemblages were characterized and compared using richness and number of occurrences of ants. Chao 2 estimates were calculated and a comparison (rarefaction analysis) of the assemblages was performed. The association of the species with the samples was evaluated by a Principal Component Analysis (PCA). Altogether, there were 1,576 occurrences of ants, totaling 55 species. The obtained estimate indicated that richness may be up to $35 \%$ higher. Our study adds important information about richness and occurrence of ants in a region poorly analyzed for this group. Most of all, it presents a survey of species occurring in agricultural ecosystems that may serve as a parameter for future evaluations when wind farms are installed.
\end{abstract}

Keywords: Atlantic forest, composition, conservation, diversity, impacted areas, richness.

\section{Assembleia de formigas (Hymenoptera: Formicidae) de três parques eólicos do estado do Paraná, Brasil}

\section{Resumo}

A transformação de ambientes naturais em áreas agrícolas ou ocupadas por empreendimentos voltados à produção de energia tem gerado uma crescente preocupação com o impacto causado por estas atividades sobre a diversidade biológica. Por isso, este estudo teve como objetivo avaliar a diversidade de formigas em agroecosistemas, na área de influência direta de três parques eólicos no município de Marmeleiro, Paraná e analisou a associação das ocorrências com os períodos das amostras. Para tanto, foram realizadas quatro amostragens durante o ano de 2013, uma por estação. Foram empregados pitfall, armadilha Malaise e rede de varredura. As assembleias foram caracterizadas e comparadas através da riqueza e do número de ocorrências das formigas. Foram construídas estimativas (Chao 2) e um comparativo (análise de rarefação) para as assembleias. A associação das espécies com as amostras foi avaliada através de uma Análise de Componentes Principais (PCA). Ao todo foram registradas 1.576 ocorrências de formigas, totalizando 55 espécies. A estimativa obtida indica que a riqueza pode ser até $35 \%$ maior. O estudo acrescenta informações importantes sobre a riqueza e ocorrências de formigas para uma região com poucos estudos deste grupo. Apresenta, sobretudo, um inventário de espécies presentes em agroecossistemas que poderá servir de parâmetro para avaliações futuras quando os parques eólicos estiverem instalados.

Palavras-chave: Mata Atlântica, composição, conservação, diversidade, áreas impactadas, riqueza. 


\section{Introduction}

Biological communities are affected by human activities and overexploitation of natural resources represents a threat to the conservation of species (Diamond, 2012). The transformation of natural environments into agricultural areas (Schneider, 1994) has generated a growing concern about the impact caused by monoculture and habitat fragmentation on the diversity of organisms (Galindo-Leal and Câmara, 2003; Zimmermann, 2009; Costa-Milanez et al., 2014; Barbosa et al., 2015). There is an increasing concern for sustainability and environmental impacts from the current energy matrix, based on burning fossil fuels, and there is the need for exploitation of renewable energy sources (Goldemberg and Lucon, 2007). However, little is yet known about the impacts caused by the exploitation of these energy sources on the richness and abundance of organisms in the directly affected areas.

In this regard, the study of ant assemblies may come to contribute, given the fact that Formicidae is one of the most diverse taxa of insects (Hölldobler and Wilson, 1990), characterized by a wide distribution, high richness and abundance in terrestrial ecosystems (Alonso and Agosti, 2000). The number of works on the occurrence of ants associated with agricultural ecosystems is growing, especially those targeting perennial crops (Rosado et al., 2012; Urrutia-Escobar and Armbrecht, 2013). However, there is a lack of studies evaluating the assemblages of ants associated with areas of semi-permanent and annual crops. The existing studies discuss ecological aspects of some species of greatest importance (Almeida et al., 2007; Chevalier et al., 2013), but do not emphasize the knowledge on diversity or aspects that affect conservation.

Wind energy is an important alternative in generating energy when compared to fossil fuel, but the environmental impacts arising from the installation and operation of wind farms are poorly understood (Barbosa Filho, 2013). During construction, known impacts are related to the removal of vegetation, removal of soil and ground compaction by machines and actions that can destroy forest remnants and disable the permanence of species of animals (Meireles, 2008). Once deployed, the wind farm may interfere with the displacement of birds and mammals (Barbosa Filho, 2013). Nonetheless, little is known about the impact on invertebrate communities.

Richness and abundance of ant assemblages in a given ecosystem is an important indicator of environmental conservation (Lutinski and Garcia, 2005). Ants are recognized as bioindicators, constituting an effective tool in evaluating environmental conditions, in the recovery of degraded areas and in monitoring regeneration of environments (Silvestre and Brandão, 2001). In this context, this study aimed to a) evaluate the diversity of ants in agroecosystems in the area under direct influence of three wind farms in the municipality of Marmeleiro, State of Paraná; b) to analyze the association of ant occurrence with sampling periods, and; c) to generate subsidies in the form of information about existing myrmecofauna, for monitoring periods after the implementation of wind farms. Studies addressing the myrmecofauna in the southwestern State of Paraná are scarce and in this sense, this study becomes important for presenting a list of species occurring in the region.

\section{Material and Methods}

\subsection{Study area}

The study was conducted in three rural areas in the municipality of Marmeleiro, southwestern State of Paraná. These are agroecosystems encompassing approximately 200 ha each, interspersed by small fragments of Atlantic rainforest (Araucaria Forest). These areas began to attract attention for research and monitoring of fauna and flora as they are in the process of transformation into wind farms to generate electricity. This is a preliminary study that precedes a monitoring upon actual installation of the farms. Farms 1 $(-26.321962,-53.127292)$ and $2(-26.336732,-53.147204)$ are contiguous with each other and will house, together, 11 turbines, while the farm $3(-26.372418,-53.087466)$ is located approximately $20 \mathrm{~km}$ far from the first two and will house 10 wind turbines. The climate is super humid, mesothermic and subtropical humid, without a distinct dry season, with frequent severe frosts and regular distribution of rainfall (Koppen, 1948). At each farm, a sampling site of approximately one hectare was randomly set. As a criterion, the site should include areas of crops and forest fragments.

\subsection{Sampling}

Four samplings were undertaken in 2013: 23rd and 24th March (summer); 7th and 8th June (fall); 31st July and 1st August (winter); and 26th and 27th September (spring). Passive (pitfalls and Malaise traps) and active (Net sweep) methods were used in all samplings.

Soil traps (pitfall) for capturing invertebrates with walking habit (Orsolon-Souza et al., 2011) consisted of $250 \mathrm{~mL}$ plastic cups (10 cm diameter, $12 \mathrm{~cm}$ height), buried with its leading edge at the ground level. Inside each trap, $150 \mathrm{~mL}$ water was added with two drops of detergent to break the surface tension of water, causing the insects to sink when they fall into the trap. Ten pitfalls were installed at each sampling site in a linear transect covering areas of crop and forest fragment. A distance of 10 meters was established between traps and these remained open for 48 hours.

The Malaise trap is recommended for flying insects. However, it is common to capture ants with this technique (Lutinski et al., 2013a). Built with plastic screen that resembles a camping tent, the Malaise trap keeps a jar receiving the insects on top of the frame. Insects tend to go upwards toward the sunlight when they hit the septa or the ceiling trap, and consequently fall into the collection cup (Almeida et al., 1998). One Malaise trap was installed in each farm, in each sample. This installation was set in transition areas between forest fragments and crops. The sampled specimens were collected at the end of 48 hours of exposure of the trap. 
The sweep net consists of a wooden handle or other lightweight material (such as aluminum), to which a metal frame and a fabric bag with rounded bottom are attached. It is indicated to catch insects in flight and can be used to capture ants present in small bushes and the undergrowth (Lutinski et al., 2013a). One hour of sweep was used in each farm. The use of this technique contemplated the ground vegetation and shrubs up to one meter high in the edge of forest fragments, tracks, crop fields and in the understory of forest fragments. The route consisted of a random walk in the environment.

\subsection{Identification of the sampled material}

The specimens collected were transferred to flasks containing $70 \%$ alcohol. In the laboratory, samples were sorted and mounted for later identification under a stereoscopic binocular microscope. Ants were identified using the literature by Gonçalves (1961), Lattke (1995), Fernandez (2003), Longino (2003) and Wild (2007).

\subsection{Statistical analysis}

Richness was defined as the number of species of ants that occurred in each of the samples. Abundance was defined based on the relative frequency (number of records of a given species in each trap) and not on the number of individuals, which minimizes the effect of foraging habits and the effect of the size of colonies and it is more appropriate for studies on ant assemblages (Romero and Jaffe, 1989). The percentage relative frequency of each species in each farm was calculated by the equation: $\mathrm{f}(\%)=\mathrm{Fi} \times 100 / \mathrm{Ft}$, where $\mathrm{Fi}$ is the number of occurrences of a given species in a given farm and $\mathrm{Ft}$ is the total number of occurrences for this farm.

Sampling sufficiency was tested by a comparison between the species found in the samples (Sobs) with the value generated by the estimator Chao 2 . This allows us to infer how much a study approaches to sample all species of a given environment (Colwell, 2006). Ant richness estimates for each farm were obtained from the software EstimateS 8.2. The richness of ants in each sampled farm was compared by a rarefaction analysis based on the samples. This analysis was performed using Ecosim 7 (Gotelli and Entsminger, 2001).

Assemblages of ants in each farm were evaluated for evenness. This index represents the contribution of each taxon in the community and was estimated by the Pielou's index (Magurran, 1988), and the analysis was obtained through the PAST software (Hammer et al., 2001).

The association of species of ants with sampling periods was analyzed by a Principal Component Analysis (PCA). Twenty- one species were excluded from analysis due to the small number of occurrences in the samples $(<=2)$. Data were previously log-transformed $(\mathrm{x}+1)$ and analyzed with the software PAST (Hammer et al., 2001).

\section{Results}

One-thousand-five-hundred and seventy-six occurrences of ants totaled 55 species, 20 genera and six subfamilies. The farm 2 had the highest richness $(\mathrm{S}=39)$, followed by
Farm $3(\mathrm{~S}=36)$ and Farm $1(\mathrm{~S}=32)$. Myrmicinae $(\mathrm{S}=23)$, Formicinae $(\mathrm{S}=17)$ and Dolichoderinae $(\mathrm{S}=8)$ were the most species-rich subfamilies. The richest genera were Camponotus $(\mathrm{S}=10)$, Pheidole $(\mathrm{S}=9)$ and Linepithema $(\mathrm{S}=6)$ (Table 1).

In the farm 1, Linepithema humile (Mayr, 1868) (31.5\%), Pheidole laevifrons Mayr, 1887 (8.5\%), Pheidole aberrans Mayr, 1868 (7.7\%), Brachymyrmex coactus Mayr, 1887 (6.9\%), Pheidole pubiventris Mayr, 1887 (5.3\%) and Solenopsis sp. (4.5\%) were the most frequent species. In the farm 2, the species that stood out were Atta sexdens (Linnaeus, 1758) (19.7\%), Pheidole sp. 2 (16.1\%), Pheidole risii Forel, $1892(9.9 \%)$ and $P$. pubiventris (8.2\%). In the farm 3, B. coactus (15.2\%), Pheidole dyctiota Kempf, 1972 (12.8\%), Solenopsis sp. (11\%), Pheidole sp. 2 (8.5\%) and Linepithema micans (Forel, 1908) (6.7\%) were the most frequent (Table 1).

The largest difference $(75.3 \%)$ between the observed (Sobs) and the estimated richness (Chao 2) was found in the farm 2. This difference was lower for the farms 1 and $3,15.75 \%$ and $14 \%$, respectively (Figure 1). The trend for increased richness from additional samples was evident in the rarefaction curves, in which none reached asymptote after the four samplings. The difference between the richness of each farm was low, but significant (Figure 2).

Higher evenness $\left(\mathrm{J}^{\prime}=0.80 \pm 0.02\right)$ was verified in the farm 3. Ant assemblages of the farms 1 and 2 were similar considering this index, $\mathrm{J}^{\prime}=0.75 \pm 0.03$ and $\mathrm{J}^{\prime}=0.75 \pm 0.02$, respectively.

The highest number of occurrences of ants $(n=492)$ was recorded in the sampling performed in the summer, however, with the lowest richness $(\mathrm{S}=32)$. The sample taken in the fall was the second with most abundant occurrences $(\mathrm{n}=481)$ and the second richest $(\mathrm{S}=36)$. The winter sample obtained only the third greatest number of occurrences $(\mathrm{n}=314)$, but the highest richness $(\mathrm{S}=39)$. The spring sample presented the lowest number of occurrences $(n=289)$ and only the third-highest richness $(\mathrm{S}=33)$.

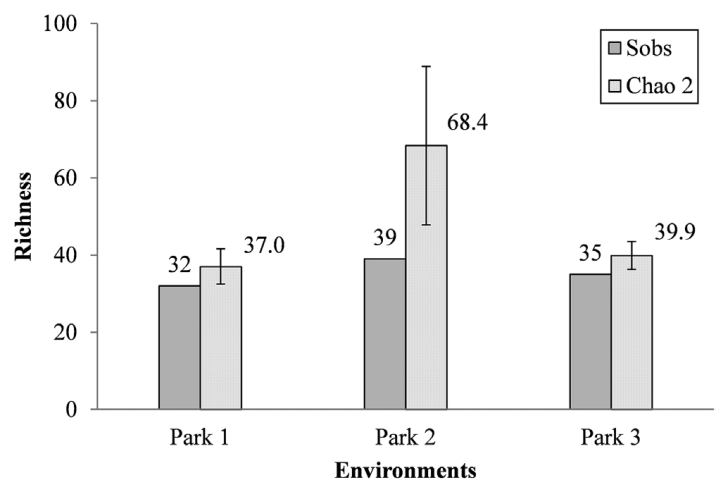

Figure 1. Observed (Sobs) and estimated (Chao 2) richness of ants with respective confidence intervals $(95 \%)$ of three wind farms located in rural municipality of Marmeleiro, Paraná (March-September, 2013). 
Table 1. Richness, occurrences (Oc) and percentage relative frequencies (prf) of ants in three wind farms located in rural municipality of Marmeleiro, Paraná (March-September, 2013).

\begin{tabular}{|c|c|c|c|c|c|c|}
\hline \multirow{3}{*}{ Taxon } & \multicolumn{6}{|c|}{ Frequencies in the samples } \\
\hline & \multicolumn{2}{|c|}{ Park 1} & \multicolumn{2}{|c|}{ Park 2} & \multicolumn{2}{|c|}{ Park 3} \\
\hline & Oc & prf (\%) & Oc & $\operatorname{prf}(\%)$ & Oc & $\operatorname{prf}(\%)$ \\
\hline \multicolumn{7}{|l|}{ Dolichoderinae } \\
\hline \multicolumn{7}{|l|}{ Dolichoderini } \\
\hline Dorymyrmex brunneus (Forel, 1908) & 1 & 0.3 & 8 & 1.3 & 6 & 1.0 \\
\hline Dorymyrmex pyramicus (Roger, 1863) & 1 & 0.3 & 1 & 0.2 & 1 & 0.2 \\
\hline Linepithema gallardoi (Brèthes, 1914) & 13 & 3.4 & & & 37 & 6.2 \\
\hline Linepithema humile (Mayr, 1868) & 119 & 31.5 & 47 & 7.9 & 38 & 6.3 \\
\hline Linepithema leucomelas (Emery, 1894) & & & 1 & 0.2 & & \\
\hline Linepithema micans (Forel, 1908) & 17 & 4.5 & 13 & 2.2 & 40 & 6.7 \\
\hline Linepithema sp. 1 & & & 3 & 0.5 & 25 & 4.2 \\
\hline Linepithema sp. 2 & 1 & 0.3 & & & 1 & 0.2 \\
\hline \multicolumn{7}{|l|}{ Ectatomminae } \\
\hline \multicolumn{7}{|l|}{ Ectatommini } \\
\hline Ectatomma edentatum Roger, 1863 & & & & & 2 & 0.3 \\
\hline \multicolumn{7}{|l|}{ Formicinae } \\
\hline \multicolumn{7}{|l|}{ Camponotini } \\
\hline Camponotus atriceps (F. Smith, 1858) & & & & & 2 & 0.3 \\
\hline Camponotus mus Roger, 1863 & 4 & 1.1 & 19 & 3.2 & 6 & 1.0 \\
\hline Camponotus rufipes (Fabricius, 1775) & & & 3 & 0.5 & 1 & 0.2 \\
\hline Camponotus sericeiventris (G.-M., 1838) & & & 6 & 1.0 & 4 & 0.7 \\
\hline Camponotus sp. 1 & 3 & 0.8 & 4 & 0.7 & & \\
\hline Camponotus sp. 2 & & & 1 & 0.2 & & \\
\hline Camponotus sp. 3 & & & & & 2 & 0.3 \\
\hline Camponotus sp. 4 & & & & & 14 & 2.3 \\
\hline Camponotus sp. 5 & & & 1 & 0.2 & & \\
\hline Camponotus sp. 6 & & & 1 & 0.2 & & \\
\hline \multicolumn{7}{|l|}{ Myrmelachistini } \\
\hline Myrmelachista sp. 1 & & & 2 & 0.3 & & \\
\hline Myrmelachista sp. 2 & 1 & 0.3 & 6 & 1.0 & & \\
\hline \multicolumn{7}{|l|}{ Plagiolepidini } \\
\hline Brachymyrmex coactus Mayr, 1887 & 26 & 6.9 & 19 & 3.2 & 91 & 15.2 \\
\hline Brachymyrmex cordemoyi (Forel, 1895) & 3 & 0.8 & 6 & 1.0 & 7 & 1.2 \\
\hline Brachymyrmex sp. & 12 & 3.2 & & & 19 & 3.2 \\
\hline Nylanderia fulva (Mayr, 1862) & & & & & 2 & 0.3 \\
\hline Nylanderia sp. & 1 & 0.3 & & & & \\
\hline \multicolumn{7}{|l|}{ Myrmicinae } \\
\hline \multicolumn{7}{|l|}{ Attini } \\
\hline Acromyrmex niger (F. Smith, 1858) & 2 & 0.5 & 1 & 0.2 & 3 & 0.5 \\
\hline Acromyrmex rugosus (F. Smith, 1858) & & & & & 3 & 0.5 \\
\hline Acromyrmex subterraneus (Forel, 1893) & & & 2 & 0.3 & 4 & 0.7 \\
\hline Atta sexdens (Linnaeus, 1758) & & & 118 & 19.7 & & \\
\hline Cyphomyrmex strigatus Mayr, 1887 & & & 1 & 0.2 & & \\
\hline \multicolumn{7}{|l|}{ Blepharidattini } \\
\hline Wasmannia auropunctata (Roger, 1863) & 4 & 1.1 & 16 & 2.7 & 4 & 0.7 \\
\hline Wasmannia sp. & 3 & 0.8 & & & & \\
\hline \multicolumn{7}{|l|}{ Cephalotini } \\
\hline Cephalotes pusillus (Klug, 1824) & 5 & 1.3 & 1 & 0.2 & 14 & 2.3 \\
\hline Cephalotes sp. & 1 & 0.3 & & & & \\
\hline
\end{tabular}


Table 1. Continued...

\begin{tabular}{|c|c|c|c|c|c|c|}
\hline \multirow{3}{*}{ Taxon } & \multicolumn{6}{|c|}{ Frequencies in the samples } \\
\hline & \multicolumn{2}{|c|}{ Park 1 } & \multicolumn{2}{|c|}{ Park 2} & \multicolumn{2}{|c|}{ Park 3} \\
\hline & Oc & $\operatorname{prf}(\%)$ & Oc & $\operatorname{prf}(\%)$ & Oc & prf $(\%)$ \\
\hline \multicolumn{7}{|l|}{ Crematogastrini } \\
\hline Crematogaster corticicola (Mayr, 1887) & & & 1 & 0.2 & & \\
\hline \multicolumn{7}{|l|}{ Formicoxenini } \\
\hline Cardiocondyla nuda (Mayr, 1866) & 3 & 0.8 & & & 5 & 0.8 \\
\hline \multicolumn{7}{|l|}{ Myrmicini } \\
\hline Pogonomyrmex naegelii Forel, 1878 & & & 2 & 0.3 & & \\
\hline \multicolumn{7}{|l|}{ Pheidolini } \\
\hline Pheidole aberrans Mayr, 1868 & 29 & 7.7 & 27 & 4.5 & 21 & 3.5 \\
\hline Pheidole dyctiota Kempf, 1972 & 8 & 2.1 & 25 & 4.2 & 77 & 12.8 \\
\hline Pheidole laevifrons Mayr, 1887 & 32 & 8.5 & 15 & 2.5 & 5 & 0.8 \\
\hline Pheidole pubiventris Mayr, 1887 & 20 & 5.3 & 49 & 8.2 & 17 & 2.8 \\
\hline Pheidole risii Forel, 1892 & 11 & 2.9 & 59 & 9.9 & 9 & 1.5 \\
\hline Pheidole sp. 1 & 8 & 2.1 & 21 & 3.5 & 9 & 1.5 \\
\hline Pheidole sp. 2 & 21 & 5.6 & 96 & 16.1 & 51 & 8.5 \\
\hline Pheidole sp. 3 & & & 2 & 0.3 & & \\
\hline Pheidole sp. 4 & & & 3 & 0.5 & & \\
\hline \multicolumn{7}{|l|}{ Solenopsidini } \\
\hline Solenopsis stricta Emery, 1896 & 4 & 1.1 & 8 & 1.3 & 9 & 1.5 \\
\hline Solenopsis sp. & 17 & 4.5 & 1 & 0.2 & 66 & 11.0 \\
\hline \multicolumn{7}{|l|}{ Ponerinae } \\
\hline \multicolumn{7}{|l|}{ Ponerini } \\
\hline Hypoponera distinguenda (Emery, 1890) & & & & & 1 & 0.2 \\
\hline Pachycondyla striata F. Smith, 1858 & 3 & 0.8 & 2 & 0.3 & & \\
\hline \multicolumn{7}{|l|}{ Pseudomyrmecinae } \\
\hline \multicolumn{7}{|l|}{ Pseudomyrmecini } \\
\hline Pseudomyrmex flavidulus (F. Smith, 1858) & 1 & 0.3 & & & & \\
\hline Pseudomyrmex gracilis (Fabricius, 1804) & 2 & 0.5 & 2 & 0.3 & 2 & 0.3 \\
\hline Pseudomyrmex termitarius (F. Smith, 1855) & & & 5 & 0.8 & 2 & 0.3 \\
\hline Pseudomyrmex sp. & 2 & 0.5 & & & & \\
\hline Number of occurrences & 378 & & 598 & & 600 & \\
\hline
\end{tabular}

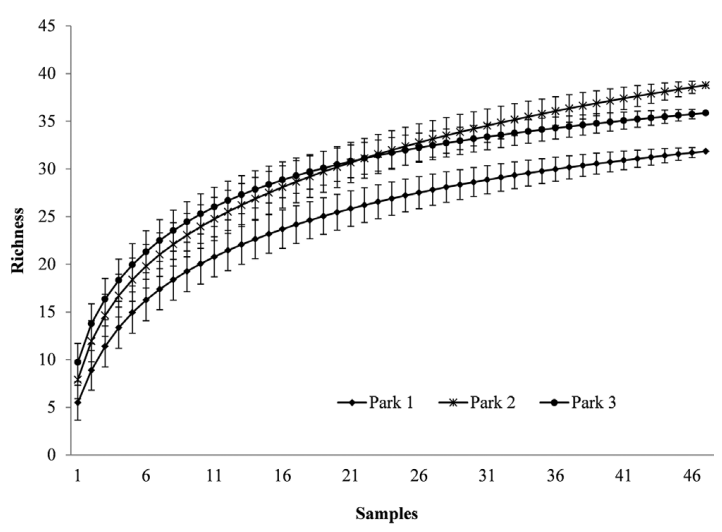

Figure 2. Comparison by the rarefaction method based on the number of samples, the accumulated richness of three wind farms located in rural municipality of Marmeleiro, Paraná (March-September, 2013). The vertical bars differentiate the curves by the standard deviation.
Altogether, $81 \%$ of the variation in ant occurrence, according to the sampling periods, was explained by PCA 1 (eigenvalue: 0.67 ; \% of variance: 63.5 ) and PCA 2 (eigenvalue: $0.18 ; \%$ of variance: 17.5 ). Six species showed a positive association with the sample taken in the summer: A. sexdens, Camponotus mus Roger, 1863, B. coactus, Linepithema gallardoi (Brèthes, 1914), P. aberrans and P. dyctiota; two with the sampling conducted in the spring: P. pubiventris and Solenopsis sp.; four with the sampling in the fall: L. micans, P. laevifrons, P. risii and Solenopsis stricta Emery, 1896; and two with the sampling in the winter: Linepithema sp. 1 and Pheidole sp. 1 (Figure 3).

\section{Discussion}

The myrmecofauna identified in this study is significant as it increases the richness of ants known in the region from 27 (Maciel et al., 2011) to 55 species. Assemblages of ants present in each farm are diversified and consist of 


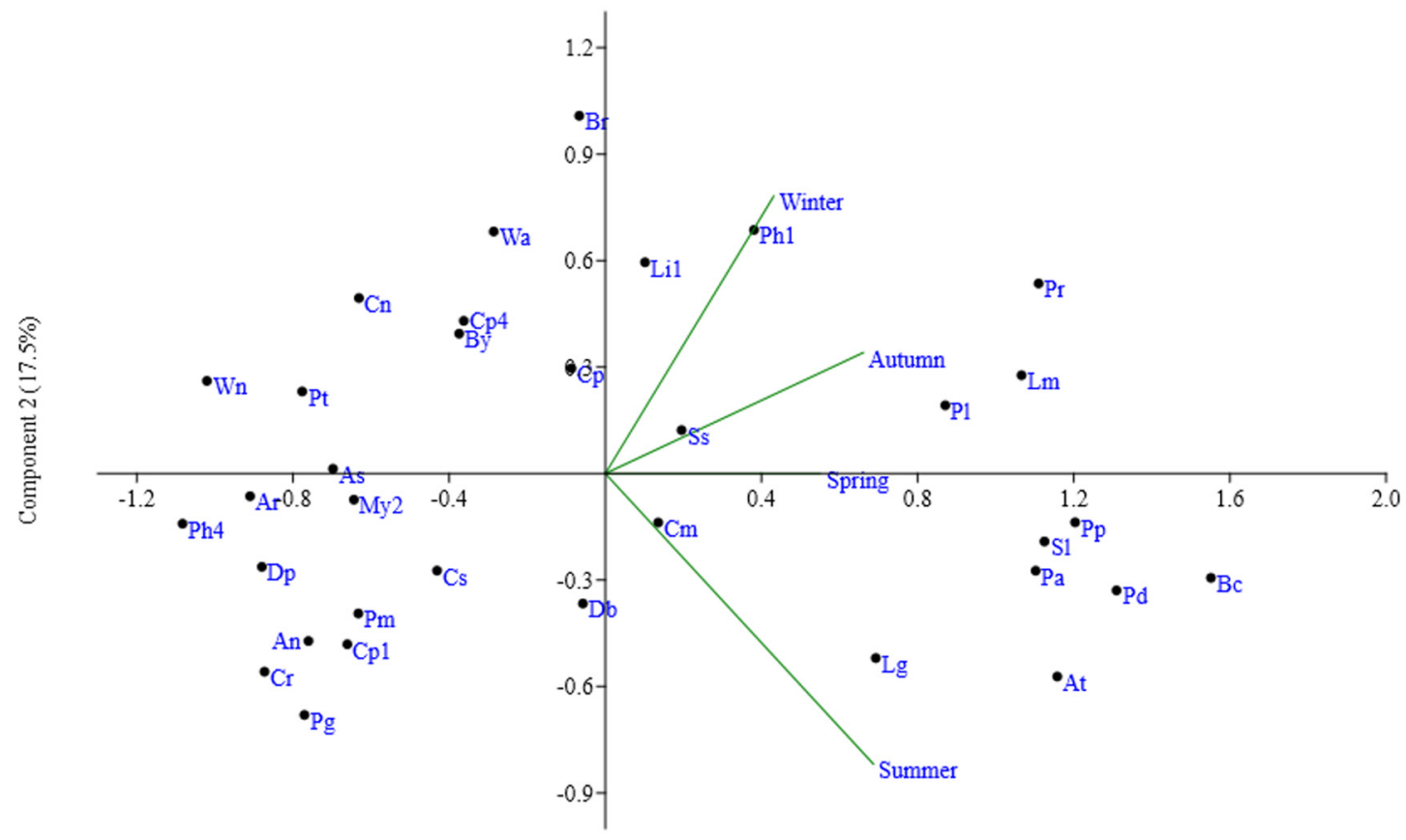

Component $1(63.5 \%)$

Figure 3. Association, by the Principal Component Analysis (PCA), of species of three wind farms located ants in rural municipality of Marmeleiro, Paraná State, with the seasons when they were sampled (March-September, 2013). An: Acromyrmex niger (F. Smith, 1858); Ar: Acromyrmex rugosus (F. Smith, 1858); As: Acromyrmex subterraneus (Forel, 1893); At: Atta sexdens (Linnaeus, 1758); Bc: Brachymyrmex coactus Mayr, 1887; By: Brachymyrmex cordemoyi (Forel, 1895); Br: Brachymyrmex sp.; Cm: Camponotus mus Roger, 1863; Cr: Camponotus rufipes (Fabricius, 1775); Cs: Camponotus sericeiventris (Guérin-Méneville, 1838); Cp1: Camponotus sp. 1; Cp4: Camponotus sp. 4; Cn: Cardiocondyla nuda (Mayr, 1866); Cp: Cephalotes pusillus (Klug, 1824); Db: Dorymyrmex brunneus (Forel, 1908); Dp: Dorymyrmex pyramicus (Roger, 1863); Lg: Linepithema gallardoi (Brèthes, 1914); Lm: Linepithema micans (Forel, 1908); Li1: Linepithema sp. 1; My2: Myrmelachista sp. 2; Pt: Pachycondyla striata F. Smith, 1858; Pa: Pheidole aberrans Mayr, 1868; Pd: Pheidole dyctiota Kempf, 1972; Pl: Pheidole laevifrons Mayr, 1887; Pp: Pheidole pubiventris Mayr, 1887; Pr: Pheidole risii Forel, 1892; Ph1: Pheidole sp. 1; Ph4: Pheidole sp. 4; Pg: Pseudomyrmex gracilis (Fabricius, 1804); Pm: Pseudomyrmex termitarius (F. Smith, 1855); Ss: Solenopsis stricta Emery, 1896; S1: Solenopsis sp.; Wa: Wasmannia auropunctata (Roger, 1863); Wn: Wasmannia sp.

subfamilies and genera with characteristics recognized for their importance in various trophic levels of the ecosystem (Hölldobler and Wilson, 1990), indicating the existence of favorable conditions for permanence and sustenance of this diversity. Evenness values above 0.75 in the three farms indicate uniformity in the distribution of abundance. The small difference between farms indicates homogeneity of agroecosystems, with similar biotic and abiotic factors for all the three environments. The occurrence of ants was influenced by the period when the samples were taken.

The recorded species of Dolichoderinae are typical of anthropogenic environments. Dorymyrmex and Linepithema genera include an important richness of ants occurring in southern Brazil (Ulysséa et al., 2011; Lutinski et al., 2013b) and play a strong dominance over food resources and recruit massively. According to Fernández (2003) and Kamura et al. (2007), some of the most important species of ants with potential to become pests, especially
L. humile, belong to these genera. The omnivorous character of these ants and the occurrence of eight species of these two genera is indicative of ecological imbalance in the areas of the farms.

The richest genus in this study was Camponotus. Ants of this genus have variable size. Approximately 400 species are described for the Neotropics, among which is observed a pronounced polymorphism and very often omnivory. They can be found foraging from the ground to the treetops. Chemical defense and mutualism are usually observed in relationships with other organisms (Silvestre et al., 2003). Camponotus mus, Camponotus rufipes (Fabricius, 1775) and Camponotus sericeiventris (G.-M., 1838) are widely distributed in the State of Santa Catarina (Ulysséa et al., 2011), being common in anthropogenic environments (Lutinski et al., 2013b).

Ants of Pheidole and Solenopsis genera are omnivorous and dominant in soil. The high diversity of ants of these 
genera in the Neotropics makes common the record of dozens of species in local studies. The wide geographic distribution and the great dispersal ability make some of these species to become locally abundant. Silvestre et al. (2003) associate these genera with the nesting in the soil, forming large colonies of small individuals, monomorphic or dimorphic, with general and aggressive behavior and a strong association with disturbed environments. This condition of environmental impact is observed in the areas of the three farms, which are occupied by agriculture, with only small forest remnants.

The association of insect fauna with forest remnants may explain the occurrence of ant genera, such as Cephalotes, Myrmelachista and Pseudomyrmex, whose species need shelter and nesting place in the vegetation. Cephalotes ants are essentially arboreal and rarely come to the ground. They are associated with vegetation, their source of supply and place to build their nests, so that they are very dependent on good local flora conditions (Fernandez, 2003; Silvestre et al., 2003). Pseudomyrmex ants are agile and lonely foragers with well-developed vision and diurnal habit. Among the approximately 180 species described for the Neotropics, most are associated with vegetation. Many are dependent on myrmecophilous plants, visit nectaries and some of them hunt on the ground. They prefer closed and humid forests, although some can be found in open areas (Ward, 2003). Myrmelachista ants have few millimeters and can be found inside seeds. Although restricted to the Neotropics, they have a wide geographical distribution (Fernández, 2003). The intimate association with flora gives them bioindicator properties, as the species richness may be positively correlated with the degree of environmental conservation.

Four leaf-cutting ants, three Acromyrmex and one Atta, were recorded. These ants are widely known, both in the scientific community, as in the popular medium. These species present the greatest potential to cause economic damage coming from environmental imbalances that result in population imbalances of these ants and lead to increased mass of plants cut (Fernández, 2003). These polymorphic ants, endemic to the Neotropics, play an important role in soil maintenance, the place they use to build their nests. Their galleries play a key role in soil aeration while their excrements and waste vegetable, enriching the soil (Silvestre et al., 2003).

The occurrence of Ectatomma and Hypoponera emphasizes the importance of conservation of leaf litter, where these ants find shelter and prey and are known as specialized predators. According to Lattke (2003), ants of these genera, share, beyond the predator habit, the habit of building their nests in fallen logs, under rocks or in leaf litter. They are identified in the field by their low agility, formation of small colonies, reduced size and a constriction between the first and second gastral segments. They have affinity to shaded and humid environments and prey upon small invertebrates without specific preference.

The Chao 2 estimator showed that the richness of ants in the three wind farms may be, on average, $35 \%$ higher than that observed. The effort required to sample all the species in a given environment can be up to 10 times higher than the original effort (Chao et al., 2009). Considering the environmental homogenization of the areas of the farms and the sampled richness, it can be said that the sampling techniques were appropriate, as well as the sampling effort applied.

Ant species distribution in the farms was relatively homogeneous considering the results pointed out by the evenness index. According to Pinto-Coelho (2000), this index varies between zero and one, and when the result is superior to 0.5 , it is considered an indicative of uniformity in the distribution of species in the assessed site. The results of the rarefaction analysis suggest small differences in richness of ants in the three farms, indicating the existence of similar factors acting on the myrmecofauna in these agroecosystems. Small forest fragments, although isolated, have significant potential for the conservation of ant species (Lutinski et al., 2013b) and may contribute to the existence of rich assemblages, even in areas of conventional agriculture.

The highest richness observed under lower temperatures (winter) can be an indicator of the complexity of factors that are acting on the local flora and also the degree of disturbance in the farms. Periods of increased activity in the soil and use of pesticides (spring and summer) may be associated with the occurrence of fewer species in the samples. However, it was clear the association of some ant species with the sampling periods (PCA). A greater number of positively associated species and a higher number of occurrences in summer samples were expected, once many species of ants have greater activity at higher temperatures (Hölldobler and Wilson, 1990).

This study adds important information about richness and occurrence of ants in a region where this group is poorly known. Moreover, the study presents a survey of species able to survive in agroecosystems under intensive and conventional management and may serve as a parameter for future evaluations when wind farms are installed. The study also points out the occurrence of some ant species associated with samples taken at different times of the year, suggesting a multitude of factors acting in these environments.

\section{Acknowledgements}

To the Chapecó Region Community University for providing their laboratories for the screening and identification of samples.

\section{References}

ALMEIDA, F.S., QUEIROZ, J.M. and MAYHÉ-NUNES, A.J., 2007. Distribuição e abundância de ninhos de Solenopsis invicta Buren (Hymenoptera: Formicidae) em um agroecossistema diversificado sob manejo orgânico. Floresta e Ambiente, vol. 14 , no. 1 , pp. 33-43. 
ALMEIDA, L.M., COSTA, C.S.R. and MARINONI, L., 1998. Manual de coleta, conservação, montagem e identificação de insetos. Ribeirão Preto: Holos Editora. 78 p.

ALONSO, L.E. and AGOSTI, D., 2000. Biodiversity studies, monitoring, and ants: an overview. In: D. AGOSTI, J.D. MAJER, L.E. ALONSO and T.R. SCHULTZ. Ants: standard methods for measuring and monitoring biodiversity. Washington: Smithsonian Institution, pp. 1-8.

BARBOSA, B.C., FAGUNDES, R., SILVA, L.F., TOFOLI, J.F.V., SANTOS, A.M., IMAI, B.Y.P., GOMES, G.G., HERMIDORFF, M.M. and RIBEIRO, S.P., 2015. Evidences that human disturbance simplify the ant fauna associated a Stachytarpheta glabra Cham. (Verbenaceae) compromising the benefits of ant-plant mutualism. Brazilian Journal of Biology = Revista Brasileira de Biologia, vol. 75, no. 1, pp. 58-68. http://dx.doi.org/10.1590/1519-6984.07213. PMid:25945621

BARBOSA-FILHO, W.P., 2013 [viewed 12 September 2015]. Impactos ambientais em usinas eólicas. In: Agrener GD 2013 [online], 15-17 maio 2013, Itajubá, Brazil. Belo Horizonte: Fundação Estadual do Meio Ambiente, pp. 1-17. Available from: http://www. feam.br/images/stories/arquivos/mudnacaclimatica/2013/ag-267.pdf

CHAO, A., COLWELL, R.K., LIN, C.W. and GOTELLI, N.J., 2009. Sufficient sampling for asymptotic minimum species richness estimators. Ecology, vol. 90, no. 4, pp. 1125-1133. http://dx.doi. org/10.1890/07-2147.1. PMid:19449706.

CHEVALIER, L.X.T., GOMES, D.S., MAYHÉ-NUNES, A.J. and QUEIROZ, J.M., 2013. Potencial de formigas (Hymenoptera: Formicidae) como agentes anti-herbívoros em cultivo de café (Coffea canephora Pierre) e Feijão Guandu [Cajanus cajans (L.) Millsp]. EntomoBrasilis, vol. 6, no. 2, pp. 113-118. http://dx.doi. org/10.12741/ebrasilis.v6i2.291.

COLWELL, R.K., 2006 [viewed 12 September 2015]. EstimateS: statistical estimation of species richness and share species from simples: version 8 [online]. Connecticut: Connecticut University Editora. Available from: http://viceroy.eeb.ucon.edu/estimates

COSTA-MILANEZ, C.B., LOURENÇO-SILVA, G., CASTRO, P.T.A., MAJER, J.D. and RIBEIRO, S.P., 2014. Are ant assemblages of Brazilian veredas characterised by location or habitat type? Brazilian Journal of Biology = Revista Brasileira de Biologia, vol . 74, no. 1, pp. 89-99. http://dx.doi.org/10.1590/1519-6984.17612. PMid:25055090.

DIAMOND, J., 2012. Colapso. 8th ed. Rio de Janeiro: Editora Record. $699 \mathrm{p}$.

FERNÁNDEZ, F., 2003. Introducción a las hormigas de la región neotropical. Bogotá: Instituto de Investigación de Recursos Biológicos Alexander von Humboldt. 426 p

GALINDO-LEAL, C. and CÂMARA, I.G., 2003. The Atlantic Forest of South America. Biodiversity status, threats, and outlook. Washington, D.C.: Island Press. 488 p.

GOLDEMBERG, J. and LUCON, O., 2007. Energia e meio ambiente no Brasil. Estudos avançados, vol. 21, no. 59, pp. 7-20.

GONÇALVES, C.R., 1961. O Gênero Acromyrmex no Brasil. Studia Entomologica, vol. 4, pp. 113-180.

GOTELLI, N.J. and ENTSMINGER, G.L., 2001 [viewed 12 September 2015]. EcoSim: null models software for ecology: versão 7.0 [online]. Victoria: Acquired Intelligence Inc. \& KeseyBear. Available from: http://homepages.together.net/ gentsmin/ ecosim.htm
HAMMER, O., HARPER, D.A.T. and RIAN, P.D., 2001 [viewed 12 September 2015]. Past: Palaeonthological statistics software package for education and data analysis: version. 1.37. Palaeontologia Electronica [online], vol. 4, no. 1,9 pp. Available from: http://palaeo-electronica.org/2001_1/past/issue1_01.htm

HÖLLDOBLER, B. and WILSON, E.O., 1990. The ants. Cambridge: Harvard University Press. 732 p.

KAMURA, C.M., MORINI, M.S.C., FIGUEIREDO, C.J., BUENO, O.C. and CAMPOS-FARINHA, A.E.C., 2007. Ant communities (Hymenoptera: Formicidae) in an urban ecosystem near the Atlantic Rainforest. Brazilian Journal of Biology = Revista Brasileira de Biologia, vol. 67, no. 4, pp. 635-641. http://dx.doi.org/10.1590/ S1519-69842007000400007. PMid:18278314.

KÖPPEN, W., 1948. Climatologia. City of México: Economic Culture Fund. $466 \mathrm{p}$

LATTKE, J.E., 1995. Revision of the ant genus Gnamptogenys in the New World (Hymenoptera: Formicidae). Journal of Hymenoptera Research, vol. 4, pp. 137-193.

LATTKE, J.E., 2003. Subfamilia Ponerinae. In: F. FERNÁNDEZ. Introducción a las hormigas de la región neotropical. Bogotá: Instituto de Investigación de Recursos Biológicos Alexander von Humboldt, pp. 261-276.

LONGINO, J.T., 2003. The Crematogaster (Hymenoptera, Formicidae, Myrmicinae) of Costa Rica. Zootaxa, vol. 151, pp. 1-150.

LUTINSKI, J.A. and GARCIA, F.R.M., 2005. Análise faunística de Formicidae (Hymenoptera: Apocrita) em ecossistema degradado no município de Chapecó, Santa Catarina. Biotemas, Florianópolis, vol. 2 , no. 18 , pp. $73-86$.

LUTINSKI, J.A., LOPES, B.C. and MORAIS, A.B.B., 2013b. Diversidade de formigas urbanas (Hymenoptera: Formicidae) de dez cidades do sul do Brasil. Biota Neotropica, vol. 13, no. 3, pp. 1-12. http://dx.doi.org/10.1590/S1676-06032013000300033.

LUTINSKI, J.A., LUTINSKI, C.J., IOP, S. and GARCIA, F.R.M., 2013a. Evaluation of an ant sampling protocol (Hymenoptera: Formicidae) in three modified environments located inside an austral Atlantic Forest area of Brazil. Ecologia Austral, vol. 23, pp. 37-43.

MACIEL, L., IANTAS, J., GRUCHOWSKI-W, F.C. and HOLDEFER, D.R., 2011. Inventário da fauna de formigas (Hymenoptera: Formicidae) em ambiente de sucessão ecológica florística no município de União da Vitória, Paraná. Biodiversida Pampeana, vol. 9, no. 1, pp. 38-43.

MAGURRAN, A.E., 1988. Ecological diversity and its measurement. New Jersey: Princeton University Press. 179 p.

MEIRELES, A.J.A., 2008 [viewed 12 September 2015]. Impactos ambientais promovidos pela implantação e operação de usinas eólicas em áreas de preservação permanente (APP's): os campos de dunas fixas e móveis da planície costeira do Cumbe, municipio de Aracati [online]. Fortaleza: Editora UFC. Available from: http://wp2.oktiva.com.br/portaldomar-bd/files/2010/08/ usinasEolicas_impactos_CUMBE2.pdf

ORSOLON-SOUZA, G., ESBÉRARD, C.E.L., MAYHÉ-NUNES, A.J., VARGAS, A.B., VEIGA-FERREIRA, S. and FOLLYRAMOS, E., 2011. Comparison between Winkler's extractor and pitfall traps to estimate leaf litter ants richness (Formicidae) at a rainforest site in southest Brazil. Brazilian Journal of Biology $=$ Revista Brasileira de Biologia, vol. 71, no. 4, pp. 873-880. http:// dx.doi.org/10.1590/S1519-69842011000500008. 
PINTO-COELHO, R.M., 2000. Fundamentos em Ecologia. Porto Alegre: Artmed Editora. 252 p.

ROMERO, H. and JAFFE, K., 1989. A comparison of methods for sampling ants (Hymenoptera: Formicidae) in Savanna. Biotropica, vol. 21, no. 4, pp. 348-352. http://dx.doi.org/10.2307/2388285.

ROSADO, J.L.O., GONÇALVES, M.G., DRÖSE, W., SILVA, E.J.E., KRÜGER, R.F., FEITOSA, R.M. and LOECK, A.E., 2012. Epigeic ants (Hymenoptera: Formicidae) in vineyards and grassland areas in the Campanha region, state of Rio Grande do Sul, Brazil. Check List, vol. 8, no. 6, pp. 1184-1189. http://dx.doi. org/10.15560/8.6.1184.

SCHNEIDER, S., 1994. O desenvolvimento agrícola e as transformações da estrutura agraria nos países desenvolvidos: a pluriatividade. Revista Reforma Agraria, vol. 24, no. 3, pp. 106-132.

SILVESTRE, R. and BRANDÃO, C.R.F., 2001. Formigas (Hymenoptera, Formicidae) atraídas a iscas em uma ilha de cerrado no município de Cajuru, estado de São Paulo, Brasil. Revista Brasileira de Entomologia, vol. 44, pp. 71-77.

SILVESTRE, R., BRANDÃO, C.R.F. and SILVA, R.R., 2003. Grupos funcionales de hormigas: el caso de los gremios del cerrado. In: F. FERNÁNDEZ. Introducción a las hormigas de la región neotropical. Bogotá: Instituto de Investigación de Recursos Biológicos Alexander von Humboldt, pp. 113-148.
ULYSSÉA, M.A., CERETO, C.E., ROSUMEK, F.B., SILVA, R.R. and LOPES, B.C., 2011. Updated list of ant species (Hymenoptera, Formicidae) recorded in Santa Catarina State, southern Brazil, with a discussion of research advances and priorities. Revista Brasileira de Entomologia, vol. 55, no. 4, pp. 603-611. http:// dx.doi.org/10.1590/S0085-56262011000400018.

URRUTIA-ESCOBAR, M.X. and ARMBRECHT, I., 2013. Effect of two agroecological management strategies on ant (Hymenoptera: Formicidae) diversity on coffee plantations in southwestern Colombia. Entomological Society of America, vol. 42, no. 2, pp. 194-203. PMid:23575008.

WARD, P.S., 2003. Subfamília Pseudomyrmecinae. In: F. FERNÁNDEZ. Introducción a las hormigas de la región neotropical. Bogotá: Instituto de Investigación de Recursos Biológicos Alexander von Humboldt, pp. 331-333.

WILD, A.L., 2007. Taxonomic revision of the ant genus Linepithema (Hymenoptera: Formicidae). University of California Publications in Entomology, vol. 126, pp. 1-159.

ZIMMERMANN, C.L., 2009. Monocultura e transgenia: impactos ambientais e insegurança alimentar. Veredas do Direito, vol. 6, no. 12 , pp. $79-100$. 